\title{
Effects of the Energy of Consciousness Healing Treatment on Physical, Spectroscopic, Thermal and Behavioral Properties of Ashwagandha Root Extract
}

\author{
Mahendra Kumar Trivedi ${ }^{1}$, Alice Branton ${ }^{1}$, Dahryn Trivedi ${ }^{1}$, Gopal Nayak ${ }^{1}$, Barry Dean Wellborn ${ }^{1}$, \\ Deborah Lea Smith ${ }^{1}$, Dezi Ann Koster ${ }^{1}$, Elizabeth Patric ${ }^{1}$, Jagdish Singh ${ }^{1}$, Kathleen Starr Vagt ${ }^{1}$, \\ Krista Joanne Callas ${ }^{1}$, Kalyan Kumar Sethi ${ }^{2}$, Parthasarathi Panda ${ }^{2}$, Snehasis Jana ${ }^{2, *}$ \\ ${ }^{1}$ Trivedi Global, Inc, Nevada, USA \\ ${ }^{2}$ Trivedi Science Research Laboratory Pvt. Ltd., Bhopal, India
}

Email address:

publication@trivedieffect.com (S. Jana)

${ }^{*}$ Corresponding author

To cite this article:

Mahendra Kumar Trivedi, Alice Branton, Dahryn Trivedi, Gopal Nayak, Barry Dean Wellborn, Deborah Lea Smith ${ }^{1}$, Dezi Ann Koster, Elizabeth Patric, Jagdish Singh, Kathleen Starr Vagt, Krista Joanne Callas, Kalyan Kumar Sethi, Parthasarathi Panda, Snehasis Jana. Effects of the Energy of Consciousness Healing Treatment on Physical, Spectroscopic, Thermal and Behavioral Properties of Ashwagandha Root Extract. American Journal of Applied Chemistry. Vol. 5, No. 2, 2017, pp. 28-37. doi: 10.11648/j.ajac.20170502.12

Received: February 24, 2017; Accepted: March 8, 2017; Published: April 1, 2017

\begin{abstract}
Withania somnifera (Ashwagandha) root extract contains lot of biologically active metabolites, which have a broad range of pharmacological activities. The current study was designed to evaluate the effects of The Trivedi Effect ${ }^{\circledR}$ - Energy of Consciousness Healing Treatment (Biofield Energy Healing Treatment) on the physical, spectroscopic, thermal and behavioral properties of ashwagandha root extract using PXRD, PSD, FT-IR, UV-vis spectroscopy, TGA, and DSC analysis. Ashwagandha root extract was divided into two parts - one part was control without any Biofield Energy Treatment and another part was treated with the Energy of Consciousness Healing Treatment remotely by seven renowned Biofield Energy Healers and defined as The Trivedi Effect $^{\mathbb{B}}$ treated sample. The PXRD analysis exhibited that both the treated and control samples were amorphous in nature. The particle size values at $d_{10}, d_{50}$, and $d_{90}$ of the treated sample were decreased by $8.41 \%, 0.51 \%$, and $7.88 \%$, respectively compared with the control sample. The surface area analysis revealed that the surface area of the treated sample was significantly increased by $5 \%$ compared to the control sample. The FT-IR analysis indicated the alteration of the force constant for the functional groups of the treated sample in comparison to the control sample. The UV-vis analysis revealed that the wavelength for the maximum absorbance of the control and treated samples were at 205.3 and $205.0 \mathrm{~nm}$, respectively. The TGA analysis revealed that the total weight loss was decreased by $0.65 \%$ in the treated sample compared with the control sample. The DSC analysis indicated that the onset, peak, and endset vaporization temperature of the treated sample were significantly increased by $41.97 \%, 23.51 \%$, and $8.82 \%$, respectively as compared to the control sample. The latent heat of vaporization $(\Delta \mathrm{H})$ of the treated $(239.96 \mathrm{~J} / \mathrm{g})$ sample was significantly increased by $39.84 \%$ compared with the control (171.60 J/g) sample. This indicated that the treated sample was thermally more stable as compared to the control sample. The current findings suggested that The Trivedi Effect ${ }^{\circledR}$ - Energy of Consciousness Healing Treatment (Biofield Energy Healing) might have the astounding capacity to enhance the solubility, absorption, dissolution, and bioavailability of ashwagandha root extract in various form of pharmaceutical and nutraceutical formulation by modifying its particle size and surface area. Thus, the treated ashwagandha root extract might provide better therapeutic response against against inflammatory diseases, immunological disorders, stress, arthritis, cancer, diabetes, sexual disorders, aging and other chronic infections.
\end{abstract}

Keywords: Withania somnifera, Biofield Energy Healing Treatment, Biofield Energy Healers, Consciousness Energy Healing, The Trivedi Effect ${ }^{\circledR}$, Particle Size, TGA, DSC 


\section{Introduction}

The importance of the herbal medicines in the prevention and treatment of the various diseases have been increased day-by-day throughout the world due to its impressive therapeutic effects and fewer side effects as compared to the modern medicines [1]. The roots of Withania somnifera (L.) Dunal (Family- Solanaceae) - a vital Rasayana herb is traditionally known as 'Ashwagandha' or winter cherry. In Ayurveda, it is called as 'Indian ginseng'. Ashwagandha is widely used in the most of the Indian herbal drugs and nutraceuticals for the treatment of various diseases including nervous and sexual disorders, infectious diseases, diabetes, cancer, ulcer, immunological disorders, stress, arthritis, etc. From the ancient time, it is used as a tonic to arrest the ageing process, rejuvenate the body and boost the defense against infectious disorders and also promote the longevity [2-11]. As ashwagandha root extract contains a wide array of nutrients and phytochemicals, it is used as a dietary supplement for the health restoration [3]. The major active phytoconstituents of ashwagandha root extract are highly oxygenated withanolides. Withanolides have C28 steroidal nucleus with C9 side chain, having a six membered lactone ring (Figure 1). The oxidation at various sites of skeleton is responsible for the structural deviations in different classes of withanolides [11-14].

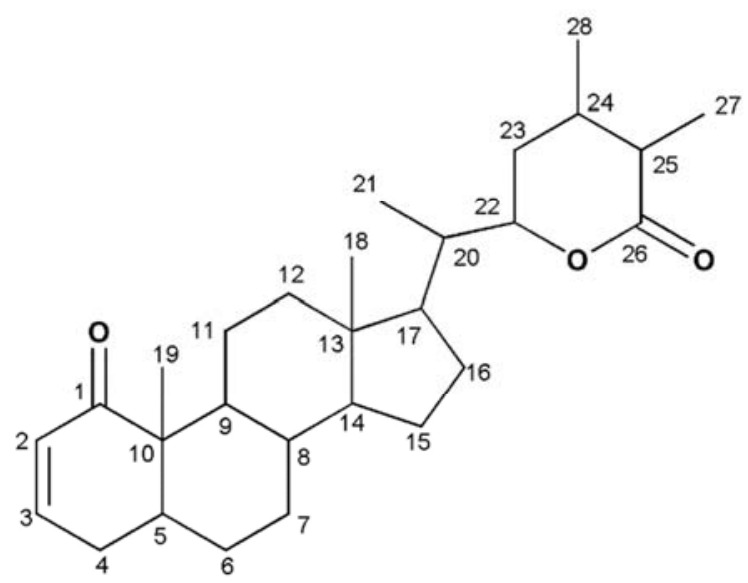

Figure 1. Basic skeleton of withanolide.

Literatures reported that withanolides such as withaferin A, withanolide $\mathrm{D}$, withanolide $\mathrm{E}$, etc. possess various pharmacological activities including antioxidant, anticancer, immunomodulating, neuroprotective, antiepileptic, antibacterial, adaptogenic, spermatogenic, antidepression, antianxiety, hepatoprotective, anti-inflammatory, antiarthritic, antimicrobial, hypoglycaemic, hypolipidemic, aphrodisiac, antiulcer, radiosensitizing, etc. [11, 14-19]. Therefore, a new proprietary herbomineral formulation was formulated that consisted of herbal product like ashwagandha root extract along with minerals such as zinc, magnesium and selenium. This herbomineral formulation is designed as nutraceutical supplement and can be used for the prevention and treatment of various human disorders.
From the ancient-time, the living force preserved by every living organisms that contributes the 'life' is defined as prana by the Hindus, qi or chi by the Chinese, and $k i$ by the Japanese. This is believed to co-relate with the soul, spirit and mind. This hypothetical vital force is considered now as the Bioenergetics Field. The Biofield Energy Field is a dynamic electromagnetic field existing surround of the human body. The Biofield Energy is infinite and paradimensional. It can freely flow between the human and environment that leads to the continuous movement or matter of energy $[20,21]$. Thus, the human has the ability to harness energy from the earth, the "universal energy field" and transmit it to any living or nonliving object (s) around the globe. The objects always receive the energy and respond in a useful way. This process is known as Biofield Energy Healing Treatment [22, 23]. Biofield (Putative Energy Fields) based Energy Therapies are used worldwide to promote health and healing [24]. The National Center of Complementary and Integrative Health (NCCIH) has been recognized and accepted Biofield Energy Healing as a Complementary and Alternative Medicine (CAM) health care approach in addition to other therapies, medicines and practices such as natural products, deep breathing, yoga, Tai Chi, Qi Gong, chiropractic/osteopathic manipulation, meditation, massage, special diets, homeopathy, progressive relaxation, guided imagery, acupressure, acupuncture, relaxation techniques, hypnotherapy, healing touch, movement therapy, pilates, rolfing structural integration, mindfulness, Ayurvedic medicine, traditional Chinese herbs and medicines, naturopathy, essential oils, aromatherapy, Reiki, cranial sacral therapy, and applied prayer (as is common in all religions, like Christianity, Hinduism, Buddhism and Judaism) [25]. The Biofield Energy Treatment (The Trivedi Effect ${ }^{\circledR}$ ) has been extensively studied with significant outcomes in many scientific fields such as cancer research [26]; altered antimicrobial sensitivity of pathogenic microbes in microbiology [27-29], biotechnology [30, 31], genetics $[32,33]$; altered structure of the atom in relation to the various metals, ceramics, polymers and chemicals materials science [34-36]; altered physical and chemical properties of pharmaceuticals [37, 38], nutraceuticals [39, 40], organic compounds [41-43]; and improved overall growth and yield of plants in agricultural science [44, 45]. Herbal extracts and it's formulations despite of their outstanding in vitro results exhibited poor or negligible in vivo activity, because of their low lipid solubility or improper molecular size, causing in deprived absorption and thus poor bioavailability [1]. According to the recent study on the bioavailability of major withanolides of Withania somnifera, Devkar et al. demonstrated that the nonpolar and low molecular weight withanolides are highly permeable, whereas the high glycosylated and polar withanolides displayed low permeability in their in vitro absorption model system [46]. For instance, ashwagandha root extract has the outstanding nutrition and medicinal values, researchers are still working on to find out an optimal dosage range for 
reproducing the desired effects in human as well as to determine the safe, non-toxic and effective dosage form [47]. The physicochemical properties such as particle size, crystalline structure, crystallite size, surface area, etc. and thermal properties of a drug play a vital role in bioavailability as well as stability of the drug during processing, formulation, storage, and packaging [48, 49]. Biofield Energy Treatment (The Trivedi Effect ${ }^{\mathbb{R}}$ ) has been reported to change the particle size, specific surface area, crystalline, chemical and thermal behavior of an atom/ion through possible mediation of neutrinos [50]. By considering all these aspect, the objective of the current study was to examine whether the Biofield Energy Treatment can change the physical, structural, and thermal properties of ashwagandha root extract in such a way that might be assist in the improvement of the solubility and absorption of ashwagandha root extract and also help in designing of any suitable pharmaceutical formulation. The physical, spectroscopic, and thermal properties of both control and the Biofield Energy Treated ashwagandha root extracts were evaluated using various analytical techniques include Fourier transform infrared (FT-IR) spectrometry, ultraviolet-visible (UV-vis) spectroscopy, Powder X-ray diffraction (PXRD), particle size distribution analysis (PSD), thermogravimetric analysis (TGA), and differential scanning calorimetry (DSC).

\section{Materials and Methods}

\subsection{Chemicals and Reagents}

Withania somnifera (Ashwagandha) root hydroalcoholic extract was purchased from Sanat Product Ltd., India. All other chemicals used in the experiment were of analytical grade available in India.

\subsection{Energy of Consciousness Healing Treatment Strategies}

Ashwagandha root extract powder was one of the components of the new proprietary herbomineral formulation, developed by our research team, and it was used per se as the test compound for the current study. The test compound was divided into two parts, one part of the test compound was treated with The Trivedi Effect ${ }^{\circledR}$ - Energy of Consciousness Healing Treatment (Biofield Energy Healing) by renowned Biofield Energy Healers and defined as The Trivedi Effect ${ }^{\circledR}$ treated sample, while the second part of the test compound did not receive any sort of such treatment and defined as untreated or control ashwagandha root extract sample. The Trivedi Effect ${ }^{\circledR}$ treatment was provided by the group of seven renowned Biofield Energy Healers who participated in this study and performed the Biofield Energy Treatment (The Trivedi Effect ${ }^{\mathbb{R}}$ ) remotely. All seven Biofield Energy Healers were remotely located in the U.S.A., while the test compound was located in the research laboratory of GVK Biosciences Pvt. Ltd., Hyderabad, India. This The Trivedi Effect ${ }^{\circledR}$ - Energy of Consciousness Healing Treatment was provided for 5 minutes through Healer's Unique Energy Transmission process remotely to the test compound under the laboratory conditions. None of the Biofield Energy Healers in this study visited the laboratory in person, nor had any contact with the compounds. Similarly, the control compound was subjected to "sham" healers for 5 minutes, under the same laboratory conditions. The sham healer did not have any knowledge about Biofield Energy Treatment. After that, the treated and untreated samples were kept in similar sealed conditions and characterized thoroughly by PXRD, PSD, FT-IR, UV-visible spectroscopy, TGA, and DSC analysis.

\subsection{Characterization}

\subsubsection{Powder X-ray Diffraction (PXRD) Analysis}

The PXRD analysis was accomplished on PANalytical X'pert Pro powder X-ray diffractometer system. The X-ray of wavelength $1.54056 \AA$ was used. The data was collected in

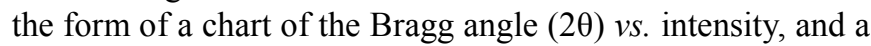
detailed table containing information on peak intensity counts, d value $(\AA)$, relative intensity (\%), full width half maximum (FWHM) $\left(\theta^{\circ}\right)$. From the XRD results, the crystallite size $(G)$ was calculated using $X$ 'pert data collector and X'pert high score plus processing software. A total of $\sim 500 \mathrm{mg}$ of the control and treated samples individually were used for the analysis and prepared by back loading technique using the sample preparation kit. The sample was spread on the holder ring in sufficient quantity to fill the ring cavity. It was then pressed down using powder press block and scrap the powder that was in surplus using a glass slide to get densely packed specimen. Consequently, the bottom plate was placed onto the holder ring and clamp in position. The sample holder was then removed from the sample preparation table by turning it upside down. A smooth surface of sample was obtained to ensure optimum results.

\subsubsection{Particle Size Distribution (PSD) Analysis}

The average particle size and particle size distribution were analyzed using Malvern Mastersizer 2000, UK with a detection range between $0.01 \mu \mathrm{m}$ to $3000 \mu \mathrm{m}$. The sample unit was filled with the dispersant medium and operated the stirrer at $2500 \mathrm{rpm}$. Alignment of the optics was done and the background measurement was taken. After the background measurement, the sample was added in to the sample unit with constant monitoring the obscuration and stopped the addition of sample when the obscuration reached in between $15 \%$ to $20 \%$. When the obscuration was stable, the measurement was taken twice and the average was taken of two measurements. The average histogram of the two measurements was recorded. Along with histogram, the data was presented in table format which include particle size $(\mu \mathrm{m})$. Also, the values at below 10\% level $\left(\mathrm{d}_{10}\right), 50 \%$ level $\left(\mathrm{d}_{50}\right)$, and $90 \%$ level $\left(\mathrm{d}_{90}\right)$, were calculated from the histogram and the calculations such as surface area $\left(\mathrm{m}^{2} / \mathrm{g}\right)$ were done by using software Mastersizer 2000.

Percent change in particle size (d) for at below $10 \%$ level $\left(\mathrm{d}_{10}\right), 50 \%$ level $\left(\mathrm{d}_{50}\right)$, and $90 \%$ level $\left(\mathrm{d}_{90}\right)$ was calculated using following equation 1 : 
$\%$ change in particle size $=\frac{\left[\mathrm{d}_{\text {Treated }}-\mathrm{d}_{\text {Control }}\right]}{\mathrm{d}_{\text {Control }}} \times 1$

Where, $\mathrm{d}_{\text {Control }}$ and $\mathrm{d}_{\text {Treated }}$ are the particle size $(\mu \mathrm{m})$ for at below $10 \%$ level $\left(\mathrm{d}_{10}\right) 50 \%$ level $\left(\mathrm{d}_{50}\right)$ and $90 \%$ level $\left(\mathrm{d}_{90}\right)$ of the control and treated samples, respectively.

Percent change in surface area (S) was calculated using following equation 2 :

$\%$ change in surface area $=\frac{\left[\mathrm{S}_{\text {Treated }}-\mathrm{S}_{\text {Control }}\right]}{\mathrm{S}_{\text {Control }}} \times 100$

Where, $\mathrm{S}_{\text {Control }}$ and $\mathrm{S}_{\text {Treated }}$ are the surface area of the control and treated samples, respectively.

\subsubsection{Fourier Transform Infrared (FT-IR) Spectroscopy}

FT-IR spectroscopy of ashwagandha root extract was performed on Spectrum two (Perkin Elmer, USA) Fourier transform infrared spectrometer with the frequency array of $400-4000 \mathrm{~cm}^{-1}$ by using pressed $\mathrm{KBr}$ disk technique.

\subsubsection{Ultra Violet-visible Spectroscopy (UV-Vis) Analysis}

The UV-Vis spectral analysis was carried out using Shimadzu UV-2450 with UV Probe, Japan. The spectrum was recorded using $1 \mathrm{~cm}$ quartz cell that has a slit width of $1.0 \mathrm{~nm}$. The wavelength range chosen for recording the spectra was $190-800 \mathrm{~nm}$. The absorbance spectra (in the range of 0.2 to 0.9 ) and wavelength of maximum absorbance $\left(\lambda_{\max }\right)$ were recorded.

\subsubsection{Thermal Gravimetric Analysis (TGA)}

TGA analysis was performed using Instrument TGA Q50 (TA Instruments, USA) at a heating rate of $10^{\circ} \mathrm{C} / \mathrm{min}$ from room temperature i.e. $30^{\circ} \mathrm{C}$ to $900^{\circ} \mathrm{C}$ under nitrogen atmosphere. A total of $\sim 13 \mathrm{mg}$ of sample was used for the analysis and was taken on the platinum pan. In TGA, the weight loss for each step was recorded in grams as well as in percent loss with respect to the initial weight. Also, the onset, endset, and peak temperature for each step were recorded in TGA.

Percent change in weight loss (W) was calculated using following equation 3 :

$$
\% \text { change in weight loss }=\frac{\left[\mathrm{W}_{\text {Treated }}-\mathrm{W}_{\text {Control }}\right.}{\mathrm{W}_{\text {Control }}} \times 100
$$

Where, $\mathrm{W}_{\text {Control }}$ and $\mathrm{W}_{\text {Treated }}$ are the weight loss of the control and The Trivedi Effect ${ }^{\mathbb{B}}$ treated samples, respectively.

\subsubsection{Differential Scanning Calorimetry (DSC)}

Analysis was performed using the DSC Q20 (TA Instruments, USA) differential scanning calorimeter. A total of $\sim 4 \mathrm{mg}$ sample was weighed and sealed in aluminum pan and equilibrated at $25^{\circ} \mathrm{C}$ and heated up to $450^{\circ} \mathrm{C}$ at the heating rate of $10^{\circ} \mathrm{C} / \mathrm{min}$ under nitrogen gas as purge atmosphere with flow rate of $50 \mathrm{~mL} / \mathrm{min}$. The value for onset, endset, peak temperature, peak height $(\mathrm{mJ}$ or $\mathrm{mW})$, peak area, and change in heat $(\mathrm{J} / \mathrm{g})$ for each peak were recorded.

Percent change in melting point $(\mathrm{T})$ was calculated using following equation 4 :
$\%$ change in melting point $=\frac{\left[\mathrm{T}_{\text {Treated }}-\mathrm{T}_{\text {Control }}\right]}{\mathrm{T}_{\text {Control }}} \times 100$

Where, $\mathrm{T}_{\text {Control }}$ and $\mathrm{T}_{\text {Treated }}$ are the melting point of the control and treated samples, respectively.

Percent change in latent heat of fusion $(\Delta \mathrm{H})$ was calculated using following equation 5 :

$\%$ change in latent heat of fusion $=\frac{\left[\Delta \mathrm{H}_{\text {Treated }}-\Delta \mathrm{H}_{\text {Control }}\right.}{\Delta \mathrm{H}_{\text {Control }}} \times 100(5)$

Where, $\Delta \mathrm{H}_{\text {Control }}$ and $\Delta \mathrm{H}_{\text {Treated }}$ are the latent heat of fusion of the control and treated samples, respectively.

\section{Results and Discussion}

\subsection{Powder X-ray Diffraction (PXRD) Analysis}

Powder X-ray diffraction study was conducted to examine the crystalline pattern of the control and treated ashwagandha root extract. The PXRD diffractograms of the control and treated ashwagandha root extracts did not contribute any diffraction peak and it was concluded that both the samples were amorphous in nature (Figure 2).
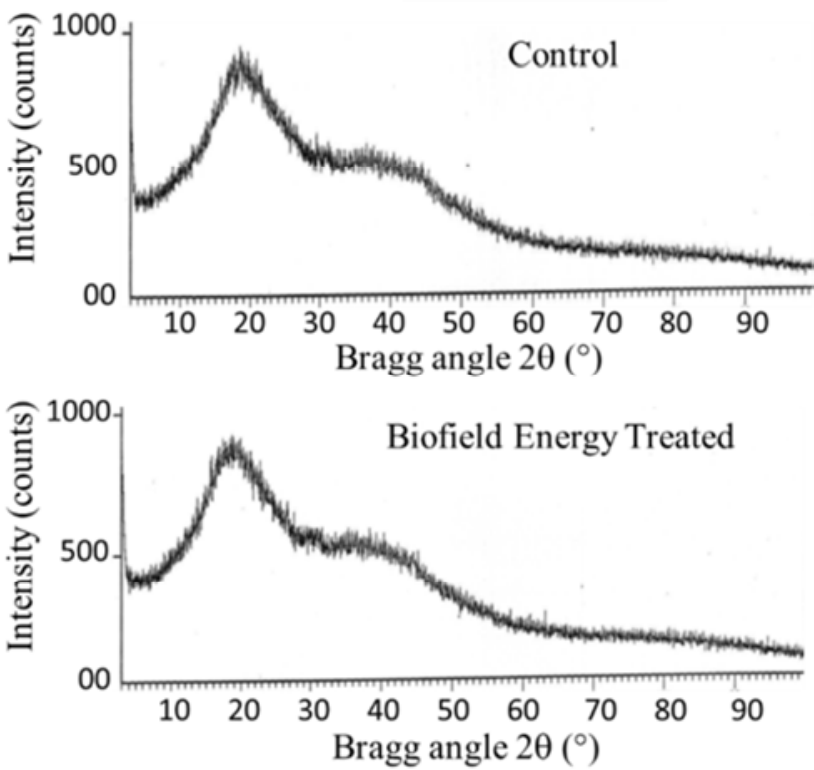

Figure 2. PXRD diffractograms of the control and Biofield Energy Treated W. somnifera (Ashwagandha) root extract.

\subsection{Particle Size Distribution (PSD) Analysis}

Particle size data $\left(\mathrm{d}_{10}, \mathrm{~d}_{50}\right.$, and $\left.\mathrm{d}_{90}\right)$ of both the control and treated ashwagandha root extract was investigated and the results are presented in Table 1. The particle size values at $\mathrm{d}_{10}, \mathrm{~d}_{50}$, and $\mathrm{d}_{90}$ of the Biofield Energy Treated ashwagandha root extract $\left(\mathrm{d}_{10}=20.90 \mu \mathrm{m}, \mathrm{d}_{50}=70.83 \mu \mathrm{m}\right.$, and $\mathrm{d}_{90}=$ $158.76 \mu \mathrm{m})$ were reduced by $8.41 \%, 0.51 \%$, and $7.88 \%$, respectively with respect to the control sample $\left(\mathrm{d}_{10}=22.82\right.$ $\mu \mathrm{m}, \mathrm{d}_{50}=71.19 \mu \mathrm{m}$, and $\mathrm{d}_{90}=172.34 \mu \mathrm{m}$ ). 
Table 1. Particle size $\left(d_{10}, d_{50}\right.$, and $\left.d_{90}\right)$ and surface area of the control and Biofield Energy Treated W. somnifera (Ashwagandha) root extract.

\begin{tabular}{|c|c|c|c|c|}
\hline Parameter & $d_{10}(\mu \mathrm{m})$ & $d_{50}(\mu \mathrm{m})$ & $d_{90}(\mu \mathrm{m})$ & $\begin{array}{l}\text { Surface area } \\
\left(\mathrm{m}^{2} / \mathrm{g}\right)\end{array}$ \\
\hline Control & 22.82 & 71.19 & 172.34 & 0.20 \\
\hline $\begin{array}{l}\text { Biofield Energy } \\
\text { Treated }\end{array}$ & 20.90 & 70.83 & 158.76 & 0.21 \\
\hline Percent change $(\%){ }^{*}$ & -8.41 & -0.51 & -7.88 & 5.00 \\
\hline
\end{tabular}

*denotes the percentage change in the particle size $\left(\mathrm{d}_{10}, \mathrm{~d}_{50}\right.$, and $\left.\mathrm{d}_{90}\right)$ and surface area of the Biofield Energy Treated sample with respect to the control sample.

The results revealed that there may be an effect of high energy milling induced through the Biofield Energy Treatment to the ashwagandha root extract. The surface area analysis of both the control and treated ashwagandha root extract revealed that the surface area of the Biofield Energy Treated ashwagandha root extract $\left(0.21 \mathrm{~m}^{2} / \mathrm{g}\right)$ was enhanced by $5 \%$ from the control sample $\left(0.20 \mathrm{~m}^{2} / \mathrm{g}\right)$. Numerous literatures mentioned that particle size, shape and surface area of the pharmaceuticals/nutraceuticals have an important impact on solubility, dissolution, in vivo bioavailability, dose uniformity and therapeutic efficacy as well as assist in the design of the new drug delivery systems [51]. Decrease in particle size and higher surface area increase the solubility of the solid particles as well as enhance the dissolution rate and bioavailability [52]. Thus, it is anticipated that The Trivedi Effect $^{\circledR}$ treated ashwagandha root extract might be absorbed in faster rate and thus, can provide better bioavailability than the untreated sample.

\subsection{Fourier Transform Infrared (FT-IR) Spectroscopy}

The FT-IR spectra of both the control and Energy of Consciousness Healing Treated samples of ashwagandha root extract are presented in Figure 3.

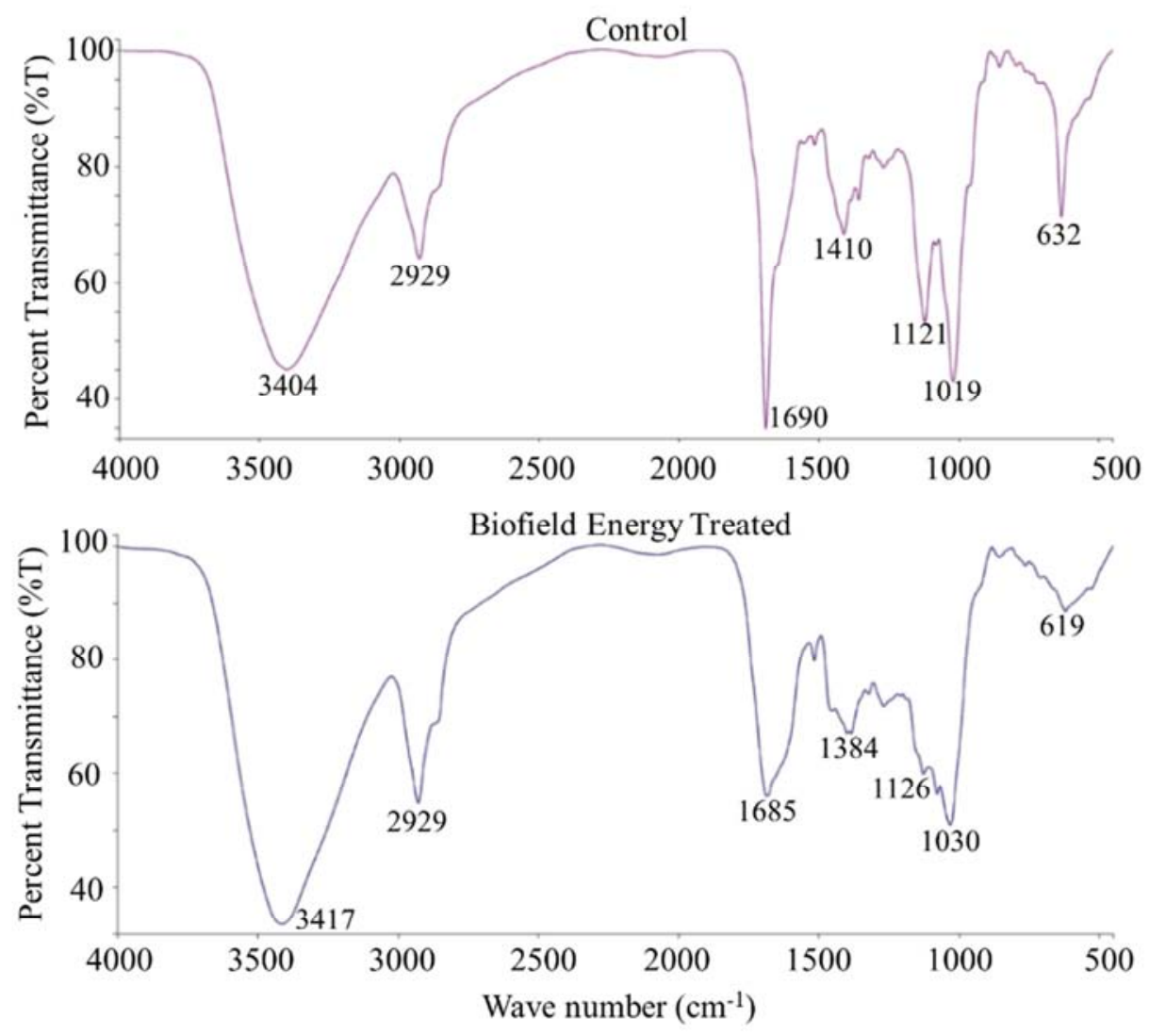

Figure 3. FT-IR spectra of the control and Biofield Energy Treated W. somnifera (Ashwagandha) root extract.

The wavenumber of the absorbance $v$ of a diatomic can be calculated from the following equation derived from the Hooke's law (Eq. 6):

$$
v=\frac{1}{2 \pi c} \sqrt{\frac{f\left(m_{1}+m_{2}\right)}{m_{1} m_{2}}}
$$

Where, $v=$ vibrational frequency $\left(\mathrm{cm}^{-1}\right), \mathrm{c}=$ the velocity of light $(\mathrm{cm} / \mathrm{s}), \mathrm{m}_{1}$ and $\mathrm{m}_{2}=$ the mass of atoms 1 and 2 , respectively, in $\mathrm{g}, \mathrm{f}=$ the force constant of the bond (dyne/cm).
From the above equation (6), it has been shown that if other factors remain constant, the vibrational frequency (wavenumber) is directly proportional to the force constant i.e. for a certain functional group (for e.g. $-\mathrm{C}=\mathrm{O}$ ), changes in the vibrational frequency (wavenumber) indicate the alteration of the force constant. Several factors such as hybridization, resonance, bond strength, conjugation, etc. can affect the force constant $[53,54]$.

From the Table 2, it has been observed that the wavenumber for the $\mathrm{O}-\mathrm{H}$ stretching, $\mathrm{C}-\mathrm{O}$ alkoxy groups of Biofield Energy Treated ashwagandha (Table 2, entry 1 and 
5) were increased compared with the control sample. It indicated that the force constant of the $\mathrm{O}-\mathrm{H}$ and $\mathrm{C}-\mathrm{O}$ groups were improved. On the other hand, the wavenumber for $\mathrm{C}-\mathrm{H}$ (alkene), $\mathrm{C}=\mathrm{O}$, C-O groups (Table 2, entry 2, 3, 4, and 6) was reduced as compared to the control sample. This results revealed that the force constant for the $\mathrm{C}-\mathrm{H}$ (alkene), $\mathrm{C}=\mathrm{O}$, $\mathrm{C}-\mathrm{O}$ groups was diminished as compared to the control sample.

Table 2. FT-IR data of the control and Biofield Energy Treated W. somnifera (Ashwagandha) root extracts.

\begin{tabular}{llll}
\hline \multirow{2}{*}{$\begin{array}{l}\text { Entry } \\
\text { No. }\end{array}$} & Mode of vibration & \multicolumn{2}{c}{$\begin{array}{l}\text { Characteristic absorption (s) of } \\
\left.\text { ashwagandha root extract } \mathbf{( c m}^{-1}\right)\end{array}$} \\
\cline { 3 - 4 } & & Control & $\begin{array}{l}\text { The Trivedi } \\
\text { Effect }^{\mathbb{Q}} \text { Treated }\end{array}$ \\
\hline 1 & O-H stretching & 3404 & 3417 \\
2 & C-H, alkanes stretching & 2929 & 2929 \\
3 & C=O stretching $(\alpha, \beta-$ & 1690 & 1685 \\
4 & unsaturated ketone) & 1410 & 1384 \\
5 & C-H, alkanes bending & 1121 & 1126 \\
6 & C-O in alkoxy & 1019 & 1030 \\
\hline
\end{tabular}

It is assumed that the alteration of the force constant for the functional groups might be due to the change in the bond strength of the functional groups of the treated sample compared to the control sample. The presence of epoxide, unsaturated lactone, 1-keto-2-ene functions play a vital role to elicit the pharmacological activities of withanolides [14, 55-57]. From the Table 2, it has been found that these type of functional groups were altered in the treated ashwagandha in comparison to the control sample. Hence, it is assumed that The Trivedi Effect ${ }^{\circledR}$ treatment might be responsible for changing the structural features of the ashwagandha root powder extract.

\subsection{Ultraviolet-Visible Spectroscopy (UV-Vis) Analysis}

The UV-visible spectra of both the control and treated ashwagandha root extracts are shown in Figure 4. The wavelength for the maximum absorbance $\left(\lambda_{\max }\right)$ of both the control and treated ashwagandha root extracts were at 205.3 and $205.0 \mathrm{~nm}$, respectively and there was a minor shift of absorbance maxima from the control sample (1.6140) to the treated sample (1.2553). It has been reported that the wavelength for the maximum absorbance for the ashwagandha root extract was at $208.50 \mathrm{~nm}$ [58]. However, no significant change in the $\lambda_{\max }$ of the treated sample was observed compared to the control sample. The UV absorbance occurs due to the different type of energy transitions from the singlet to the singlet excited state such as $\sigma \rightarrow \sigma^{*}, \mathrm{n} \rightarrow \pi^{*}, \pi \rightarrow \pi^{*}$. These type of electronic transitions are occurred when the difference in energy between the lowest unoccupied molecular orbital (LUMO) and the highest occupied molecular orbital (HOMO) is significantly higher than the activation energy of the compound [59].
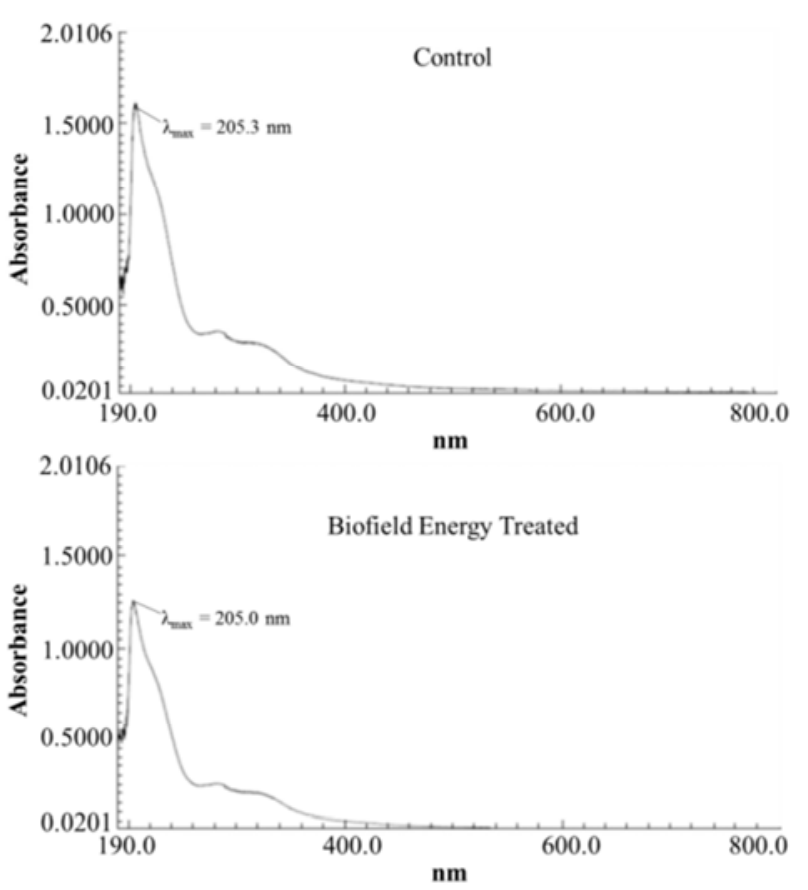

Figure 4. UV-vis spectra of the control and Biofield Energy Treated W. somnifera (Ashwagandha) root extracts.Hence, it is anticipated that the structure of the phytoconstituents in the treated sample was remained unaffected as compared to the control sample.

\subsection{Thermal Gravimetric Analysis (TGA)}

TGA was applied to investigate the thermal stability of the both control and treated ashwagandha root extracts. The TGA analysis exhibited three steps of thermal degradation as mentioned in Table 3 and Figure 5. In the $1^{\text {st }}$ and $3^{\text {rd }}$ step thermal degradation, the weight loss of the treated ashwagandha root extract $\left(1^{\text {st }}\right.$ step $=10.55 \%$ and $2^{\text {nd }}$ step $\left.=10.40 \%\right)$ were reduced by $4.09 \%$ and $4.32 \%$, respectively compared with the control sample $\left(1^{\text {st }}\right.$ step $=11.00 \%$ and $2^{\text {nd }}$ step $\left.=10.87 \%\right)$.

Table 3. Thermal degradation steps of the control and Biofield Energy Treated W. somnifera (Ashwagandha) root extract.

\begin{tabular}{|c|c|c|c|c|c|}
\hline \multirow{2}{*}{ S. No. } & \multicolumn{2}{|c|}{ Temperature $\left({ }^{\circ} \mathrm{C}\right)$} & \multicolumn{2}{|c|}{ \% Weight loss } & \multirow{2}{*}{$\begin{array}{l}\% \\
\text { Change }\end{array}$} \\
\hline & Control & Treated & Control & Treated & \\
\hline $\begin{array}{l}1^{\text {st }} \text { step of } \\
\text { degradation }\end{array}$ & 185.00 & 185.00 & 11.00 & 10.55 & -4.09 \\
\hline $\begin{array}{l}2^{\text {nd }} \text { step of } \\
\text { degradation }\end{array}$ & 485.00 & 485.00 & 56.59 & 57.00 & 0.72 \\
\hline $\begin{array}{l}3^{\text {rd }} \text { step of } \\
\text { degradation }\end{array}$ & 895.90 & 895.90 & 10.87 & 10.40 & -4.32 \\
\hline Total weight loss & - & - & 78.46 & 77.95 & -0.65 \\
\hline
\end{tabular}

*denotes the percentage change in the weight loss of the Biofield Energy Treated sample with respect to the control sample.

Furthermore, the weight loss of the second step degradation of the treated ashwagandha root extract $(57.00 \%)$ was decreased by $0.72 \%$ with respect to the control sample $(56.59 \%)$. However, the total weight loss of the treated sample $(77.95 \%)$ was reduced by $0.65 \%$ from the control sample $(78.46 \%)$. It is then anticipated that The Trivedi Effect $^{\circledR}$ treatment might enhance the thermal stability of the ashwagandha root extract. 

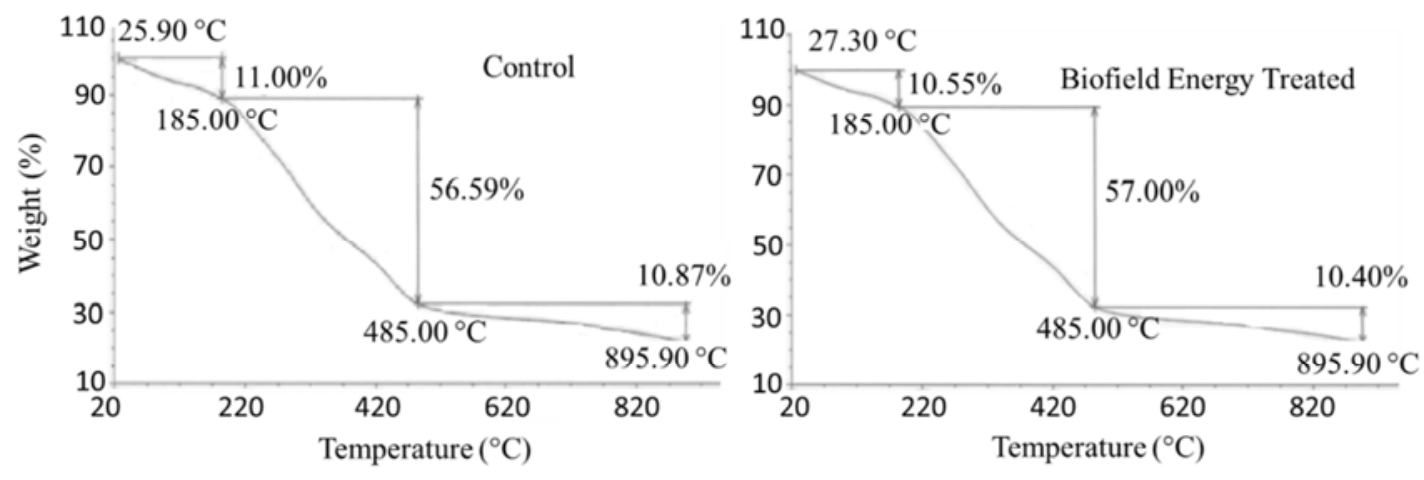

Figure 5. TGA thermograms of the control and Biofield Energy Treated W. somnifera (Ashwagandha) root extract.
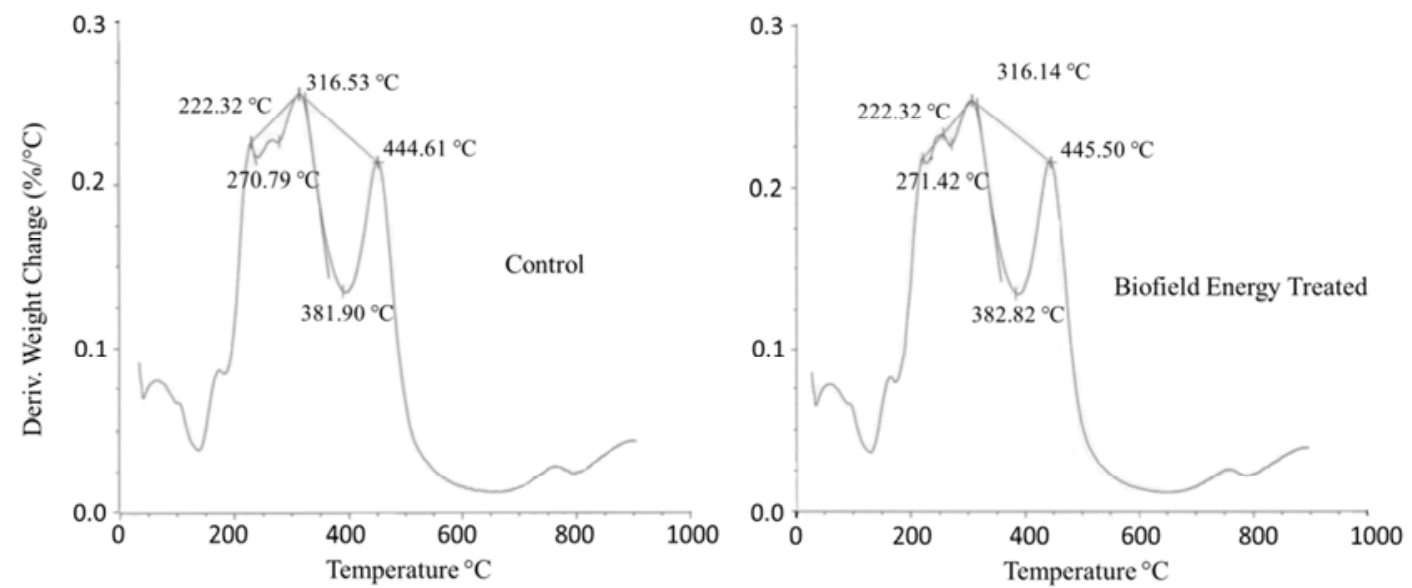

Figure 6. The DTG thermograms of the control and Biofield Energy Treated W. somnifera root extract.

Similarly, the DTG thermograms of the control and treated samples disclosed maximum temperature $\left(\mathrm{T}_{\max }\right)$ at 381.90 and $382.82^{\circ} \mathrm{C}$, respectively (Figure 6). The onset and endset degradation temperature were 316.53 and $444.61^{\circ} \mathrm{C}$, respectively for the control sample. The onset and end-set degradation temperature was observed to be 316.14 and $445.50^{\circ} \mathrm{C}$, respectively for the treated sample. The DTG analysis indicated that the decomposition temperature of the biofield treated $W$. somnifera was fractionally increased as compared to the control sample. Overall, TGA/DTG revealed miner decrease in mass loss and increase in $\mathrm{T}_{\max }$ of biofield treated $W$. somnifera as compared to the control sample. The current study indicated that there was an increased in the thermal stability of the biofield treated $W$. somnifera as compared to the control sample.

\subsection{Differential Scanning Calorimetry (DSC) Analysis}

The DSC thermograms of both the control and treated ashwagandha root extract are presented in the Figure 7 and Table 4. The DSC thermogram of the control and Biofield Energy Treated samples indicated the presence of a broad endothermic inflection at 79.36 and $98.02^{\circ} \mathrm{C}$, respectively which is not the true melting point of the treated ashwagandha root extract. It may be the evaporation of the bound water present in the sample.
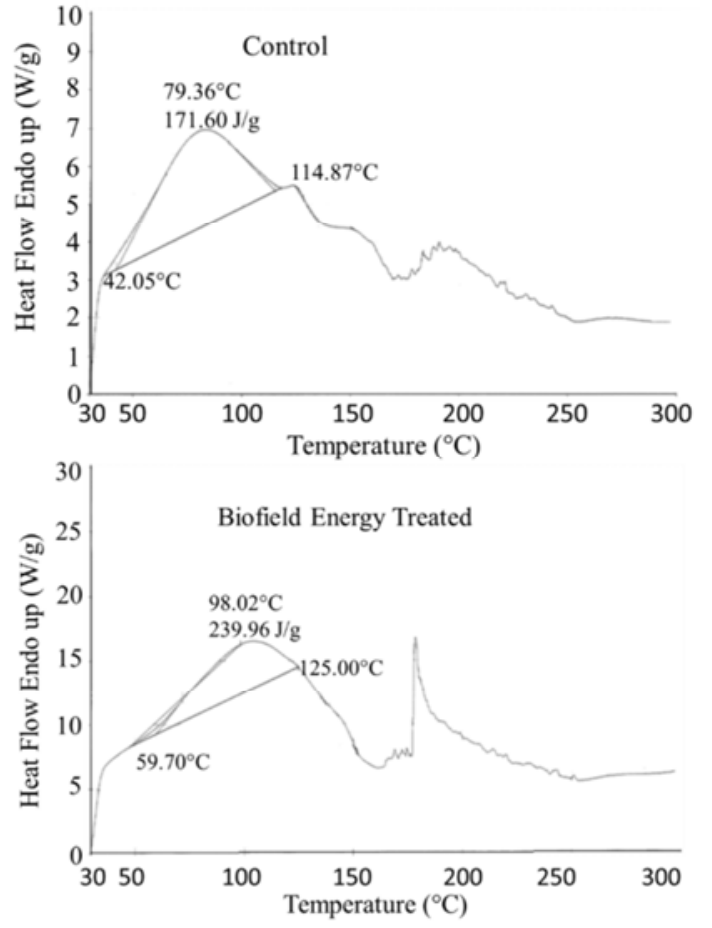

Figure 7. DSC thermograms of the control and Biofield Energy Treated W. somnifera (Ashwagandha) root extract. 
Table 4. The melting point $\left({ }^{\circ} \mathrm{C}\right)$ and latent heat of fusion $(J / G)$ values of the control and Biofield Energy Treated W. somnifera (Ashwagandha) root extract.

\begin{tabular}{lllll}
\hline Sample & $\begin{array}{l}\text { Onset vaporization } \\
\text { temperature }\left(\mathbf{T}_{\text {onset }}\right)^{\circ} \mathbf{C}\end{array}$ & $\begin{array}{l}\text { Peak vaporization } \\
\text { temperature }\left(\mathbf{T}_{\text {peak }}\right)\end{array}{ }^{\circ} \mathbf{C}$ & $\begin{array}{l}\text { Endset vaporization } \\
\text { temperature }\left(\mathbf{T}_{\text {endset }}\right)^{\circ} \mathbf{C}\end{array}$ & $\begin{array}{l}\text { Latent heat of vaporization } \\
\left(\Delta \mathbf{H}_{\text {vaporization }}\right) \mathbf{J} / \mathbf{g}\end{array}$ \\
\hline Control & 42.05 & 79.36 & 114.87 & 171.60 \\
Biofield Energy Treated & 59.70 & 98.02 & 125.00 & 239.96 \\
$\%$ Change* & 41.97 & 23.51 & 8.82 & 39.84 \\
\hline
\end{tabular}

$\mathrm{T}_{\text {onset: }}$ Onset vaporization temperature, $\mathrm{T}_{\text {peak }}$ : Peak vaporization temperature, $\mathrm{T}_{\text {endset }}$ : Endset vaporization temperature, $\Delta \mathrm{H}$ : Latent heat of vaporization, ${ }^{\mathrm{a}} \mathrm{denotes}$ the percentage change of the Biofield Energy Treated sample with respect to the control sample.

The onset, peak, and endset vaporization temperature of the Biofield Energy Treated sample were significantly improved by $41.97 \%, 23.51 \%, 8.82 \%$, respectively as compared to the control sample. Similarly the latent heat vaporization $(\Delta \mathrm{H})$ of the Biofield Energy Treated sample, also increased significantly by $39.84 \%$ as compared to the control sample (Table 4). However, the Biofield Energy Treated, and control $W$. somnifera indicated several endothermic peak around $200^{\circ} \mathrm{C}$ respectively (Figure 6). Several small endothermic peaks were also observed in the thermogram of both in control and treated samples, which may be due to the multiple phytoconstituents present in the root extract in a very small concentration $[60,61]$. In the Biofield Energy Treated sample the endothermic peak was sharp and significantly prominent as compared to the control sample (Figure 6). It is assumed that The Trivedi Effect ${ }^{\circledR}$ Energy of Consciousness Healing Treatment might improve the intermolecular force in the treated sample, which probably increased the thermal stability of ashwagandha root extract.

\section{Conclusions}

The current research work revealed that The Trivedi Effect $^{\circledR}$ - Energy of Consciousness Healing Treatment (Biofield Energy Healing) has the outstanding capability for reduction of the particle size of the ashwagandha root extract along with enhanced surface area. The particle size values at $\mathrm{d}_{10}, \mathrm{~d}_{50}$, and $\mathrm{d}_{90}$ values of the treated sample were decreased by $8.41 \%, 0.51 \%$, and $7.88 \%$, respectively compared with the control sample. The surface area analysis revealed that the surface area of the treated sample was significantly increased by $5 \%$ as compared to the control sample. The FT-IR analysis revealed that The Trivedi Effect ${ }^{\circledR}$ - Energy of Consciousness Healing Treatment had an effect on the structural properties of the ashwagandha root extract by changing the force constant of its functional groups. The TGA analysis revealed that the total weight loss was decreased by $0.65 \%$ in the treated sample as compared to the control sample. The DSC analysis indicated that the onset, peak, and endset vaporization temperature of the treated sample were significantly increased by $41.97 \%, 23.51 \%$, and $8.82 \%$, respectively as compared to the control sample. The latent heat of vaporization $(\Delta \mathrm{H})$ of the treated $(239.96 \mathrm{~J} / \mathrm{g})$ sample was significantly increased by $39.84 \%$ compared with the control $(171.60 \mathrm{~J} / \mathrm{g})$ sample. The DSC/TGA analysis indicated that the treated sample thermally more stable as compared to the control sample. In summary, The Trivedi Effect $^{\circledR}$ treated ashwagandha root extract could be more soluble, absorbable from the gut and more bioavailable as compared to the untreated compound and be suitable for any oral pharmaceutical and nutraceutical formulation which might be providing better therapeutic response against various diseases such as diabetes mellitus, allergies and septic shock; stress-related disorders like sleep disorder, insomnia, anxiety, depression, Attention Deficit Disorder (ADD), Attention Deficit Hyperactive Disorder (ADHD), mental restlessness (mind chattering), brain frog, low libido, impotency, lack of motivation, mood swings, fear of the future, confusion, migraines, headaches, forgetfulness, overwhelm, loneliness, worthlessness, indecisiveness, frustration, irritability, chronic fatigue, obsessive/compulsive behavior and panic attacks; inflammatory diseases and immunological disorders like Lupus, Systemic Lupus Erythematosus, Hashimoto Thyroiditis, Type 1 Diabetes, Asthma, Chronic peptic ulcers, Tuberculosis, Hepatitis, Chronic active hepatitis, Celiac Disease (gluten-sensitive enteropathy), Addison Disease, Crohn's disease, Graves' Disease, Pernicious and Aplastic Anemia, Sjogren Syndrome, Irritable Bowel Syndrome (IBS), Multiple Sclerosis, Rheumatoid arthritis, Chronic periodontitis, Ulcerative colitis, Chronic sinusitis, Myasthenia Gravis, Atherosclerosis, Vasculitis, Dermatitis, Diverticulitis, Rheumatoid Arthritis, Reactive Arthritis, Alopecia Areata, Psoriasis, Scleroderma, Fibromyalgia, Chronic Fatigue Syndrome and Vitiligo; aging-related diseases like cardiovascular disease, arthritis, cancer, Alzheimer's disease, dementia, cataracts, osteoporosis, diabetes, hypertension, glaucoma, hearing loss, Parkinson's Disease, Huntington's Disease, Prion Disease, Motor Neurone Disease, Spinocerebellar Ataxia, Spinal muscular atrophy, Amyotrophic lateral sclerosis, Friedreich's Ataxia and Lewy Body Disease, chronic infections and many more.

\section{Abbreviations}

DSC: Differential scanning calorimetry, FT-IR: Fourier transform infrared spectroscopy, HOMO: Highest energy occupied molecular orbital, LUMO: Lowest energy unoccupied molecular orbital, TGA: Thermal gravimetric analysis, $\mathrm{T}_{\text {peak }}=$ Peak vaporization temperature, $\Delta \mathrm{H}$ : Latent heat of vaporization, UV-vis: Ultraviolet-visible spectroscopy, PSD: Particle size distribution; PXRD: Powder $\mathrm{X}$-ray diffraction. 


\section{Acknowledgements}

The authors gratefully acknowledged to GVK Biosciences Pvt. Ltd., Trivedi Science, Trivedi Global, Inc. and Trivedi Master Wellness for the assistance and support during the work.

\section{References}

[1] Kesarwani K, Gupta R (2013) Bioavailability enhancers of herbal origin: An overview. Asian Pac J Trop Biomed 3:253266.

[2] Singh N, Bhalla M, Jager P, Gilca M (2011) An overview on ashwagandha: A rasayana (rejuvenator) of ayurveda. Afr $\mathrm{J}$ Tradit Complement Altern Med 8:208-213.

[3] Alam N, Hossain M, Mottalib MA, Sulaiman SA, Gan SH, Khalil MI (2012) Methanolic extracts of Withania somnifera leaves, fruits and roots possess antioxidant properties and antibacterial activities. BMC Complement Altern Med 12:175.

[4] Parihar P, Shetty R, Ghafourifar P, Parihar MS (2016) Increase in oxidative stress and mitochondrial impairment in hypothalamus of streptozotocin treated diabetic rat: Antioxidative effect of Withania somnifera. Cell Mol Biol (Noisy-le-grand) 62:73-83.

[5] Choudhary B, Shetty A, Langade DG (2015) Efficacy of Ashwagandha (Withania somnifera [L.] Dunal) in improving cardiorespiratory endurance in healthy athletic adults. Ayu. 36:63-68.

[6] Halder B, Singh S, Thakur SS (2015) Withania somnifera root extract has potent cytotoxic effect against human malignant melanoma cells. PLoS One 10:e0137498.

[7] Verma SK, Kumar A (2011) Therapeutic uses of Withania somnifera (ashwagandha) with a note on withanolides and its pharmacological actions. Asian J Pharm Clin Res 4:1-4.

[8] Shah N, Singh R, Sarangi U, Saxena N, Chaudhary A, Kaur G, Kaul SC, Wadhwa R (2015) Combinations of ashwagandha leaf extracts protect brain-derived cells against oxidative stress and induce differentiation. PLoS One 10:e120554.

[9] Al-Awthan YS, Hezabr SM, Al-Zubairi AM, Al-Hemiri FA (2014) Effects of aqueous extract of Withania somnifera on some liver biochemical and histopathological parameters in male guinea pigs. Pak J Biol Sci 17:504-510.

[10] Nema R, Jain P, Khare S, Pradhan A, Gupta A, Singh D (2012) Study of Withania somnifera with the spatial reference of phytochemical, FTIR and flavonoids quantification. Int J Pharm Life Sci 3:1530-1532.

[11] Kumar V, Dey A, Hadimani MB, Marcović T, Emerald M (2015) Chemistry and pharmacology of Withania somnifera:An update. Tang (Humanitas Medicine) 5:e1.

[12] Misra L, Mishra P, Pandey A, Sangwan RS, Sangwan NS, Tuli R (2008) Withanolides from Withania somnifera roots. Phytochemistry 69:1000-1004.

[13] Lala P, Misra L, Sangwana RS, Tuli R (2006) New withanolides from fresh berries of Withania somnifera $\mathrm{Z}$. Naturforsch 61b:1143-1147.
[14] Zhao J, Nakamura N, Hattori M, Kuboyama T, Tohda C, Komatsu K (2002) Withanolide derivatives from the roots of Withania somnifera and their neurite outgrowth activities. Chem Pharm Bull 50:760-765.

[15] Budhiraja RD, Krishan P, Sudhir S (2000) Biological activity of withanolides. J Sci Ind Res 59:904-911.

[16] Baitharu I, Jain V, Deep SN, Shroff S, Sahu JK, Naik PK, Ilavazhagan $\mathrm{G}$ (2014) Withanolide A prevents neurodegeneration by modulating hippocampal glutathione biosynthesis during hypoxia. PLoS One 9:e105311.

[17] Sangwan NS, Sabir F, Mishra S, Bansal S, Sangwan RS (2014) Withanolides from Withania somnifera Dunal: Development of cellular technology and their production. Recent Pat Biotechnol 8:25-35.

[18] $\mathrm{Ku} \mathrm{SK,} \mathrm{Bae} \mathrm{JS} \mathrm{(2014)} \mathrm{Antiplatelet,} \mathrm{anticoagulant,} \mathrm{and}$ profibrinolytic activities of withaferin A. Vascul Pharmacol 60:120-126.

[19] Gao S, Li H, Zhou XQ, You JB, Tu DN, Xia G, Jiang JX, Xin C (2015) Withaferin A attenuates lipopolysaccharide-induced acute lung injury in neonatal rats. Cell Mol Biol (Noisy-le-grand) 61:102-106.

[20] Stenger VJ (1999) Bioenergetic fields. Sci Rev Alternative Med 3.

[21] Rogers, M (1989) "Nursing: A Science of Unitary Human Beings." In J. P. Riehl-Sisca (ed.) Conceptual Models for Nursing Practice. $3^{\text {rd }}$ Edn. Norwark: Appleton \& Lange.

[22] Rubik B (2002) The biofield hypothesis: Its biophysical basis and role in medicine. J Altern Complement Med 8:703-717.

[23] Nelson LA, Schwartz GE (2005) Human biofield and intention detection: Individual differences. J Altern Complement Med 11:93-101.

[24] Nemeth L (2008) Energy and biofield therapies in practice. Beginnings 28:4-5.

[25] Koithan M (2009) Introducing complementary and alternative therapies. J Nurse Pract 5:18-20.

[26] Trivedi MK, Patil S, Shettigar H, Mondal SC, Jana S (2015) The potential impact of biofield treatment on human brain tumor cells: A time-lapse video microscopy. J Integr Oncol $4: 141$.

[27] Trivedi MK, Branton A, Trivedi D, Nayak G, Gangwar M, Jana S (2015) Assessment of antibiogram of biofield energy treated Serratia marcescens. European Journal of Preventive Medicine 3:201-208.

[28] Trivedi MK, Branton A, Trivedi D, Shettigar H, Nayak G, Gangwar M, Jana S (2015) Antibiogram typing of biofield treated multidrug resistant strains of Staphylococcus species. American Journal of Life Sciences 3:369-374.

[29] Trivedi MK, Branton A, Trivedi D, Shettigar H, Nayak G, Mondal SC, Jana S (2015) Antibiogram, biochemical reactions and genotyping characterization of biofield treated Staphylococcus aureus. American Journal of BioScience 3:212220.

[30] Trivedi MK, Patil S, Shettigar H, Bairwa K, Jana S (2015) Effect of biofield treatment on phenotypic and genotypic characteristic of Provindencia rettgeri. Mol Biol 4:129. 
[31] Trivedi MK, Branton A, Trivedi D, Nayak G, Gangwar M, Jana S (2015) Bacterial identification using 16S rDNA gene sequencing and antibiogram analysis on biofield treated pseudomonas fluorescens. Clin Med Biochemistry Open Access 1:101.

[32] Trivedi MK, Branton A, Trivedi D, Nayak G, Gangwar M, Jana S (2015) Antibiogram, biochemical reactions, and genotypic pattern of biofield treated Pseudomonas aeruginosa. J Trop Dis 4:181.

[33] Trivedi MK, Branton A, Trivedi D, Nayak G, Mondal SC, Jana S (2015) Biochemical differentiation and molecular characterization of biofield treated Vibrio parahaemolyticus. American Journal of Clinical and Experimental Medicine $3: 260-267$.

[34] Trivedi MK, Tallapragada RM (2008) A transcendental to changing metal powder characteristics. Metal Powder Report 63:22-38.

[35] Dabhade VV, Tallapragada RMR, Trivedi MK (2009) Effect of external energy on the atomic, crystalline, and powder characteristics of antimony and bismuth powders. Bull Mater Sci 32:471-479.

[36] Trivedi MK, Patil S, Tallapragada RM (2013) Effect of bio field treatment on the physical and thermal characteristics of vanadium pentoxide powders. J Material Sci Eng S 11:001.

[37] Trivedi MK, Patil S, Shettigar H, Bairwa K, Jana S (2015) Spectroscopic characterization of chloramphenicol and tetracycline:An impact of biofield. Pharm Anal Acta 6:395.

[38] Trivedi MK, Patil S, Shettigar H, Bairwa K, Jana S (2015) Spectroscopic characterization of biofield treated metronidazole and tinidazole. Med Chem 5:340-344.

[39] Trivedi MK, Mohan R, Branton A, Trivedi D, Nayak G, Latiyal O, Jana S (2015) Evaluation of biofield energy treatment on physical and thermal characteristics of selenium powder. Journal of Food and Nutrition Sciences 3:223-228.

[40] Trivedi MK, Nayak G, Patil S, Tallapragada RM, Jana S, Mishra RK (2015) Bio-field treatment:An effective strategy to improve the quality of beef extract and meat infusion powder. J Nutr Food Sci 5:389.

[41] Trivedi MK, Branton A, Trivedi D, Nayak G, Singh R, Jana S (2015) Evaluation of physical, thermal and spectroscopic properties of biofield treated $p$-hydroxyacetophenone. Nat Prod Chem Res 3:190.

[42] Trivedi MK, Branton A, Trivedi D, Nayak G, Panda P, Jana S (2016) Gas chromatography-mass spectrometric analysis of isotopic abundance of ${ }^{13} \mathrm{C},{ }^{2} \mathrm{H}$, and ${ }^{18} \mathrm{O}$ in biofield energy treated $p$-tertiary butylphenol (PTBP). American Journal of Chemical Engineering 4:78-86.

[43] Trivedi MK, Branton A, Trivedi D, Nayak G, Mishra RK, Jana S (2015) Characterization of physical, thermal and spectral properties of biofield treated 2-aminopyridine. Science Journal of Analytical Chemistry 3:127-134.

[44] Trivedi MK, Branton A, Trivedi D, Nayak G, Gangwar M, Jana S (2015) Agronomic characteristics, growth analysis, and yield response of biofield treated mustard, cowpea, horse gram, and groundnuts. International Journal of Genetics and Genomics 3:74-80.
[45] Trivedi MK, Branton A, Trivedi D, Nayak G, Mondal SC, Jana S (2015) Evaluation of plant growth, yield and yield attributes of biofield energy treated mustard (Brassica juncea) and chick pea (Cicer arietinum) seeds. Agriculture, Forestry and Fisheries 4:291-295.

[46] Devkar ST, Kandhare AD, Sloley BD, Jagtap SD, Lin J, Tam YK, Katyare SS, Bodhankar SL, Hegde MV (2015) Evaluation of the bioavailability of major withanolides of Withania somnifera using an in vitro absorption model system. J Adv Pharm Technol Res 6:159-164.

[47] Verma SK, Kumar A (2011) Therapeutic uses of Withania somnifera (ashwagandha) with a note on withanolides and its pharmacological actions. Asian J Pharm Clin Res 4:1-4.

[48] Chereson R (2009) Bioavailability, bioequivalence, and drug selection. In:Makoid CM, Vuchetich PJ, Banakar UV (eds) Basic pharmacokinetics ( $1^{\text {st }}$ edn) Pharmaceutical Press, London.

[49] Blagden N, de Matas M, Gavan PT, York P (2007) Crystal engineering of active pharmaceutical ingredients to improve solubility and dissolution rates. Adv Drug Deliv Rev 59:617-630.

[50] Trivedi MK, Mohan TRR (2016) Biofield energy signals, energy transmission and neutrinos. American Journal of Modern Physics 5:172-176.

[51] Khadka P, Ro J, Kim H, Kim I, Kim JT, Kim H, Cho JM, Yun G, Lee J (2014) Pharmaceutical particle technologies:An approach to improve drug solubility, dissolution and bioavailability. Asian J Pharm Sci 9:304-316.

[52] Buckton G, Beezer AE (1992) The relationship between particle size and solubility. Int J Pharmaceutics 82:R7-R10.

[53] Reichenbacher M, Popp J (2012) Challenges in Molecular structure determination, DOI 10.1007/978-3-642-24390-5_2, Springer-Verlag Berlin Heidelberg.

[54] Stuart BH (2004) Infrared spectroscopy:Fundamentals and applications in Analytical Techniques in the Sciences. John Wiley \& Sons Ltd., Chichester, UK.

[55] Joshi P, Misra L, Siddique AA, Srivastava M, Kumar S, Darokar MP (2014) Epoxide group relationship with cytotoxicity in withanolide derivatives from Withania somnifera. Steroids 79:19-27.

[56] Misra L, Lal P, Chaurasia ND, Sangwan RS, Sinha S, Tuli R (2008) Selective reactivity of 2-mercaptoethanol with $5 \beta, 6 \beta$-epoxide in steroids from Withania somnifera. Steroids 73:245-251.

[57] Gu M, Yu Y, Gunaherath GMKB, Leslie Gunatilaka AA, Li D, Sun D (2014) Structure-activity relationship (SAR) of withanolides to inhibit $H s p 90$ for its activity in pancreatic cancer cells. Invest New Drugs 32:68-74.

[58] Ramachandran A, Kumar MS (2014) FT-IR, UV and antimicrobial activity Withania somnifera and Withania obtusifolia. Int J Pharm Bio Sci 5:(B) 111-117.

[59] Hesse M, Meier H, Zeeh B (1997) Spectroscopic methods in organic chemistry, Georg Thieme Verlag Stuttgart, New York.

[60] Srivastava A, Alam S, Shahbaaz S, Tiwari M, Mittal A, Chauhan $S$ (2014) Formulation and evaluation of antiacne cream containing Withania somnifera. J Pharm Sci Inv 3:348-352.

[61] Mitra D, Francis S, Varshney L (2004) Calorimetry thermal investigations on $\gamma$ radiation processed natural medicinal products (ashwagandha, amla and hartiki) J Therm Anal Cal 78:821-829. 